\title{
E-Commerce Application System at Motorcycle Showroom
}

\author{
Bambang Triraharjo, Phong Thanh Nguyen, Eswaran Perumal, K. Shankar, Satria Abadi, \\ Wahidah Hashim, Andino Maseleno
}

\begin{abstract}
Bampringsewu Motor Showroom is a business engaged with sale of used motorcycles. The development of sale technology makes the company wants to expand its scope and provide convenience for its customers. Making a web-based application that can simplify and benefit businesses for their owner and customer. Business and sale can be done on a website to make it easier for company and customer, for example customer no longer need to come directly to the showroom to see the motorbikes in the showroom. The owner realizes that not all of customers can have a lot of time to be able to come directly to the showroom. Therefore, designing this website can be a media and convenience between owner and customer.
\end{abstract}

Keywords : E-commerce, Motorcycle, business, web-based.

\section{INTRODUCTION}

Nowadays, the development of information technology is growing rapidly. Many businesses use information technology to support and develop their business performance. Web-based online media is currently being sought by business actors as a supporting factor in developing a business. One of them is website. Website used as an online media so people can more easily get information.

As a new private business established in 2012 and engaged in the sale of used motorcycles, the growing BAMPRINGSEWU MOTOR Showroom has an increase in customer every year and can begin to compete with other showrooms. The problem with Bampringsewu Motor Showroom is all information is still provided manually, so customer must come directly to the showroom to find out what used motorcycles are available in the showroom. This way is certainly not efficient for customer who do not has much time. Owner also often experience delays in receiving

Revised Manuscript Received on July 22, 2019.

* Correspondence Author

Bambang Triraharjo, Department of Information Systems, STMIK Pringsewu, Lampung, Indonesia.

Phong Thanh Nguyen*, Department of Project Management, Ho Chi Minh City Open University, Vietnam. E-mail: phong.nt@ou.edu.vn

Eswaran Perumal, Department of Computer Applications, Alagappa University, Karaikudi, India. E-mail: eswaranperumal@gmail.com

K. Shankar, Department of Computer Applications, Alagappa University, Karaikudi, India. E-mail: shankarcrypto@gmail.com

Satria Abadi, Department of Information Systems, STMIK Pringsewu, Lampung, Indonesia.

Wahidah Hashim, Institute of Informatics and Computing Energy, Universiti Tenaga Nasional, Malaysia.

Andino Maseleno, Institute of Informatics and Computing Energy,

Universiti Tenaga Nasional, Malaysia. car sales report in the showroom so it can inhibit the owner from controlling the company's performance.

Therefore, a web-based used motorcycle sale application is made to facilitate customer in getting information without having to come directly to the showroom.

\section{Research Problem}

1. How to increase sales promotion of used motorcycle?

2. How to manage used motorcycle sales data?

3. How to overcome the problem of the slow making of used motorcycle sales report?

\section{Research Objectives}

1. Building a web-based sales application to expand sales promotion of used motorcycle.

2. Making a web-based used motorcycle sales data management application.

3. Completing the application for admin in overcoming the problem of the slow making of used motorcycle sales report.

\section{Scope of the Research}

Within the limitation of the problem to be discussed, it is limited to the limitations of the E-commerce design which covers the scope of the Bampringsewu Motor Showroom located in the East Pringsewu sub-district, Pringsewu Sub-district, Pringsewu Regency.

\section{THEORITICAL FRAMEWORK}

\subsection{System Definition}

System is the totality of the structure consisting of elements, where each of these elements has a special function, and they interact with each other, they interact in an effort to achieve common goal.

\subsection{Information Definition}

Information is the result of data processing which in principle has a value compared to raw data". Information According to Gordon B. Davis is data that has been processed into an important form for decisions making and has a tangible value that can be felt in the current or future decisions.

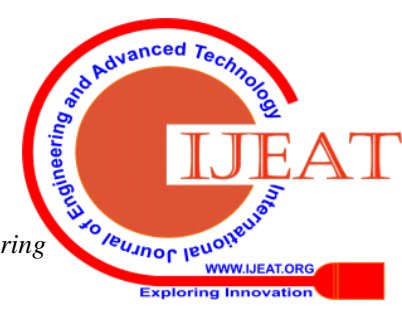




\subsection{Definition of Information System}

The information system is a tool for presenting information in such a way that is beneficial for the recipient. The aim is to present information for decision making in planning, initiating, organizing, controlling the operation of a company that presents organizational synergy in process. Information system is a system within an organization that meets the needs of processing daily transaction, supports operation, managerial and strategic activities of an organization and provides certain external parties with the necessary report.

\subsection{Definition of Application}

Application is the use in a computer, instruction or statement is arranged in such a way that the computer can process the input into output. While definition of the application according to Indonesia Dictionary is the application of a system design to process data using rules or certain programming language requirements. An application is a computer program created to do and carry out specific task from the user.

\subsection{Definition of E-Commerce}

E-Commerce is a process of buying and selling products electronically by consumer and from company to company with computer as intermediaries for business transaction. E-Commerce is the use of computer network to conduct business communication and commercial transaction.

\subsection{Definition of Database}

According to Bambang Hariyanto (2004), database is a collection of data (elementer) logically related to representing phenomena / fact structured in certain domain to support application on certain system. Meanwhile, according to Ilberschatz, et al. (2002), defines databases as data sets containing information that is appropriate for a company.

\subsection{Definition of Data Flow Diagram (DFD)}

According to Wijaya (2007) Data Flow Diagram (DFD) is graphic image that show the flow of data from its source in an object and then go through a process that transforms to another destination, which is on another object. Thus, the data flow diagram is a tool used to describe the flow of data through the system and the work or processing carried out by the system.

\subsection{Definition of Website}

Website is an information system site page that can be accessed quickly. This website is based on the development of information and communication technology. Through the development of information technology, a network of interconnected computers is created. Network known as the internet continually become electronic message, including e-mail, file transmission, and two-way communication between individual or computer. According to Boone (Thomson), the Web is a collection of rich graphical sources of information that are interconnected with one another on the larger internet. Meanwhile, according to Yuhefizar, Web is a method for displaying information on the internet, both in form of interactive text, image, sound and video and has the advantage to link one document with other documents (hypertext) that can be accessed through a browser.

\subsection{Definition of ERD}

Entity Relationship Diagram (ERD) is a conceptual modeling specifically designed to identify entities that explain data and relationship between data.

\section{RESEARCH METODOLOGY}

Systems development methodology is methods, procedures, work concepts, rules which will be used to develop an information system. The methodology that researcher used was the waterfall methodology, the waterfall method provided a schematic or sequential approach to the software's life cycle starting from the analysis, design, coding, testing, and support stages.

\section{System survey}

In this stage, several activities were carried out which included defining the problem that existed at the Bampringsewu Motor Showroom to determine the scope, determining the methodology used, and schedule activities using several data collection techniques such as interview and observation.

\section{System analysis}

In this stage, an analysis of the existing system is done by identifying problem, determining the purpose of improving a system, and identifying the need of system user at the Bampringsewu Motor Showroom.

\section{Coding}

It should be translated into a software program. The result of this stage is a computer program in accordance with the design that was created at the design stage.

\section{Testing}

Testing focused on software in a logical and functional way and ensured that all parts have been tested. This is done to minimize errors and ensured the resulting output as desired.

\section{Support or Maintenance}

The possibility of a software experienced changes when it has been sent to the user. Changes could be occur due to errors that appear and are not detected during testing or the software should adapt to the new environment. The support or maintenance phase can repeat the development process starting from specification analysis to change the existing software, but not to create new software.

\section{DESIGNING AND IMPLEMENTATION}

The system design can be divided into several sections in accordance with the stages that have been applied to the design method, namely:

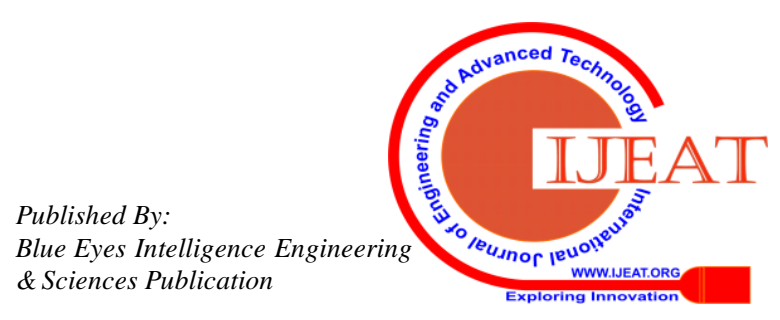




\subsection{Context Diagram}

In this case, it has been explained through the flow chart of the document flow process on used motorcycle sales information system at the Bampringsewu Motor Showroom, and for the following will be illustrated also a context diagram showing a used motorcycle sales information system process at the Bampringsewu Motor Showroom namely as follows:

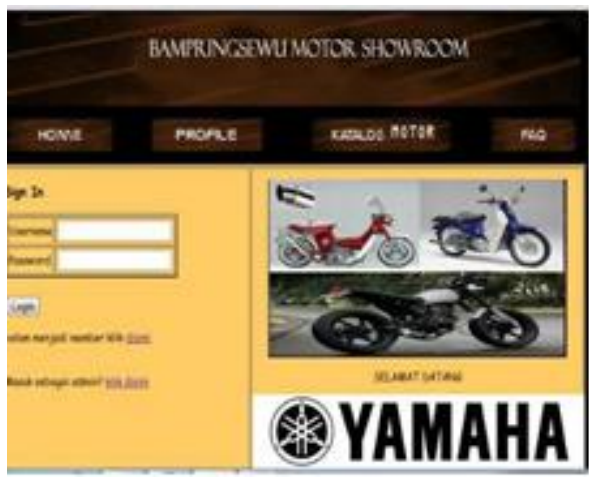

Figure 4.1 index page
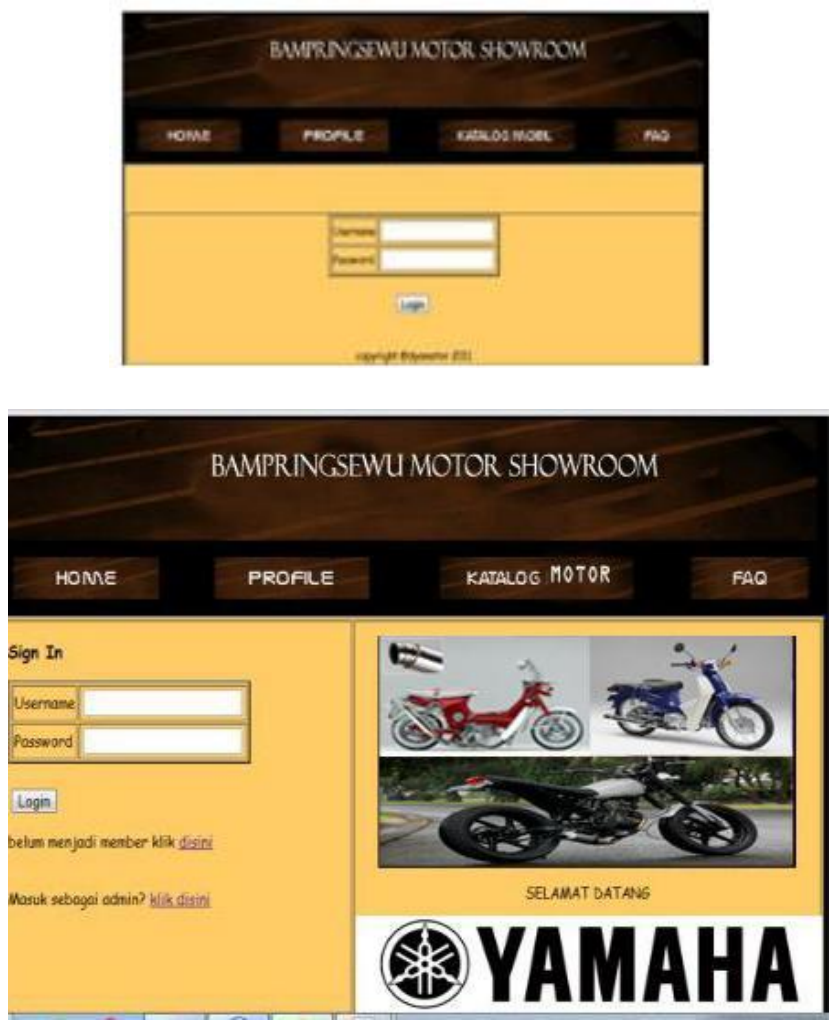

Figure 4.2 admin login page

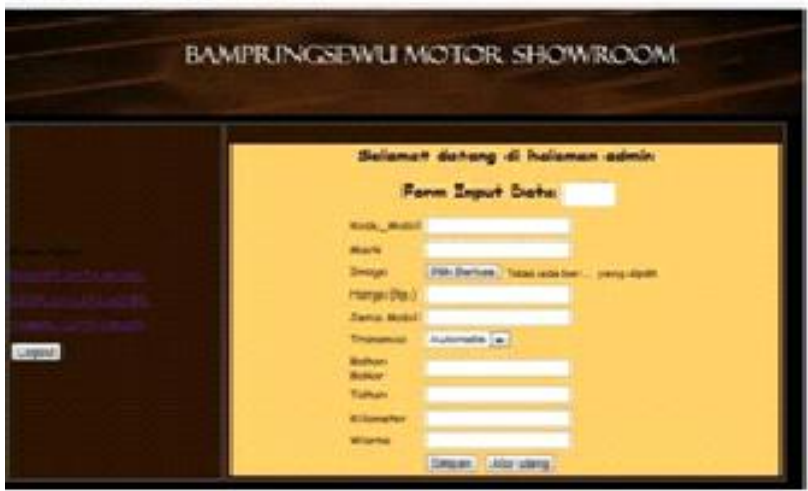

Figure 4.3 Insert Motor Data Page

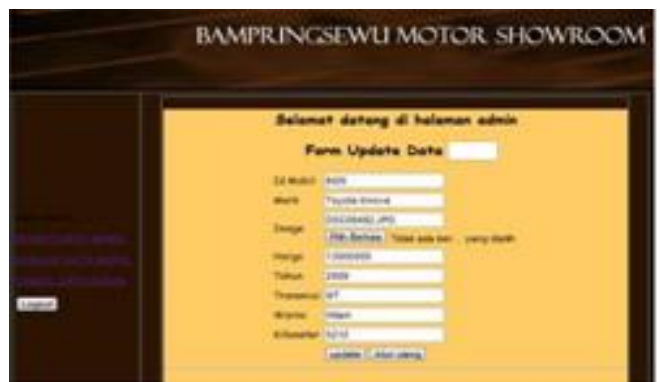

Figure 4.4 Motor Data Edit Page

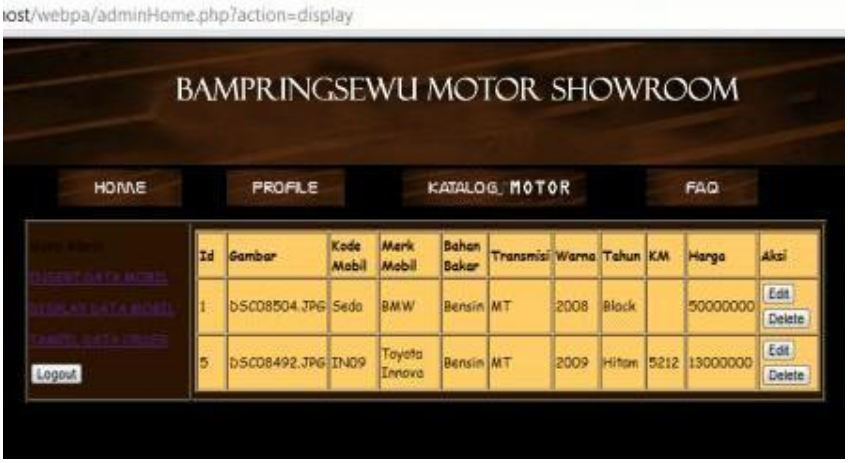

Figure 4.5 Motor Data Display Page

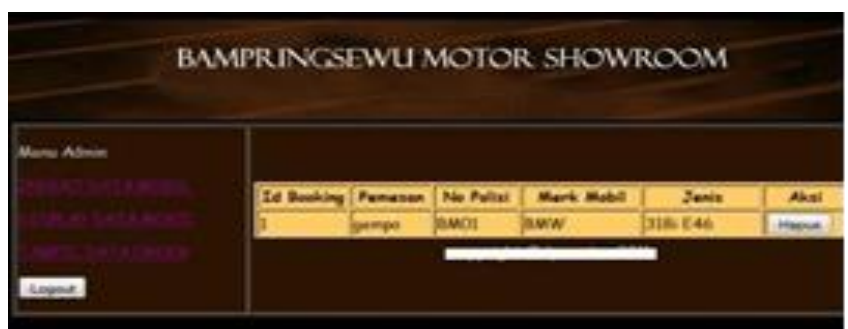

Figure 4.6 Motor Order Data Page

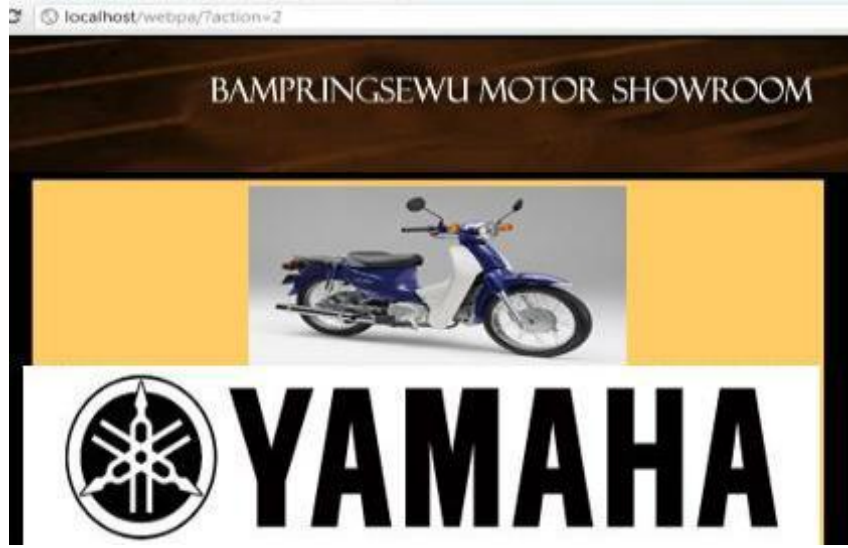

Figure 4.7 Consumer Profile Page

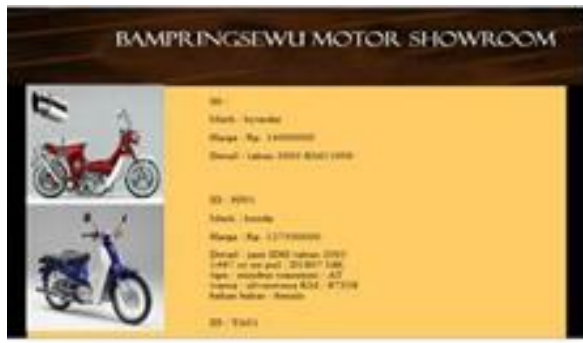

Figure 4.8 Catalog of Motorcycle for Consumer Page

Published By:

Blue Eyes Intelligence Engineering \& Sciences Publication

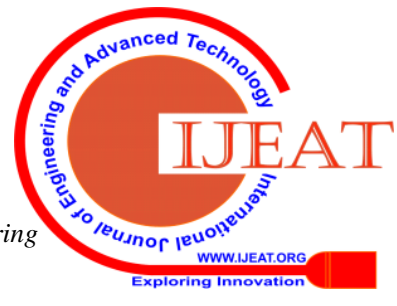




\section{CONCLUSION AND SUGGESTION}

\section{A. Conclusion}

From this series of application tests, it can be concluded that:

1. This application could expand sales promotion of used motorcycle.

2. This application could manage motorcycle sales data

3. This application could overcome the problem of the slow making of motorcycle sales reports.

\section{B. Suggestion}

Suggestions for developing the web-based used motorcycle sales application at the Bampringsewu motor showroom are:

1. There was an online payment system, where consumer no longer need to difficult to solve payment problem that sometimes take a lot of time.

2. There was good delivery system where consumer no longer needed to come directly to the showroom to be able to see the motorcycle they wants.

\section{REFERENCES}

1. Jermsittiparsert, K., Sutduean, J., Sriyakul, T., \& Khumboon, R. 2019. "The Role of Customer Responsiveness in Improving the External Performance of an Agile Supply Chain." Polish Journal of Management Studies 19 (2): 206-217.

2. Jermsittiparsert, K., Sutduean, J., \& Sriyakul, T. 2019. "Effect of Service Innovation and Market Intelligence on Supply Chain Performance in Indonesian Fishing Industry.” Industrial Engineering \& Management Systems 18 (3): 408-417.

3. Jermsittiparsert, K., Namdej, P., \& Somjai, S. 2019. “Green Supply Chain Practices and Sustainable Performance: Moderating Role of Total Quality Management Practices in Electronic Industry of Thailand." International Journal of Supply Chain Management 8 (3): 33-46.

4. Somjai, S. \& Jermsittiparsert, K. 2019. "The Trade-off between Cost and Environmental Performance in the Presence of Sustainable Supply Chain.” International Journal of Supply Chain Management 8 (4): $237-247$

5. Jermsittiparsert, K. \& Sawasdee, A. 2012. "Formal Education for Non-Thai or Undocumented Person in Thailand amidst the Challenge of Nationalism and Transnationalism: A Case Study of Wat Sirimongkhol School, Samut Sakhon Province." Kasetsart Journal - Social Sciences 33 (2): 203-213.

6. Chienwattanasook, K., Wattanapongphasuk, W., Prianto, A., \& Jermsittiparsert, K. 2019. "Corporate Entrepreneurship and Business Performance of Logistic Companies in Indonesia." Industrial Engineering \& Management Systems 18 (3): 538-547.

7. Dawabsheh, M., Hussein, A., \& Jermsittiparsert, K. 2019. "The Triangular Relationship between TQM, Organizational Excellence and Organizational Performance: A Case of Arab American University Palestine.” Management Science Letters 9 (6): 921-932.

8. Maseleno, A., Hardaker, G., Sabani, N., \& Suhaili, N. (2016). Data on multicultural education and diagnostic information profiling: Culture, learning styles and creativity. Data in brief, 9, 1048.

9. Maseleno, A., Huda, M., Jasmi, K. A., Basiron, B., Mustari, I., Don, A. G., \& bin Ahmad, R. (2019). Hau-Kashyap approach for student's level of expertise. Egyptian Informatics Journal, 20(1), 27-32.

10. Maseleno, A., Huda, M., Siregar, M., Ahmad, R., Hehsan, A. Haron, Z., ... \& Jasmi, K. A. (2017). Combining the previous measure of evidence to educational entrance examination. Journal of Artificial Intelligence, 10(3), 85-90.

11. Chienwattanasook, K. \& Jermsittiparsert, K. 2019. "Impact of Entrepreneur Education on Entrepreneurial Self-Employment: A Case Study from Thailand." Polish Journal of Management Studies 19 (1): 106-116.

12. Jermsittiparsert, K., Siam, M., Issa, M., Ahmed, U., \& Pahi, M. 2019. "Do Consumers Expect Companies to Be Socially Responsible? The Impact of Corporate Social Responsibility on
Buying Behavior." Uncertain Supply Chain Management 7 (4): 741-752.

13. Syazali, M., Putra, F., Rinaldi, A., Utami, L., Widayanti, Umam, R., \& Jermsittiparsert, K. 2019. "Partial Correlation Analysis Using Multiple Linear Regression: Impact on Business Environment of Digital Marketing Interest in the Era of Industrial Revolution 4.0.' Management Science Letters 9 (11): 1875-1886.

14. Sae-Lim, P. \& Jermsittiparsert, K. 2019. "Is the Fourth Industrial Revolution a Panacea? Risks toward the Fourth Industria Revolution: Evidence in the Thai Economy." International Journal of Innovation, Creativity and Change 5 (2): 732-752.

15. Chatchawanchanchanakij, P., Arpornpisal, C., \& Jermsittiparsert, K 2019. "The Role of Corporate Governance in Creating a Capable Supply Chain: A Case of Indonesian Tin Industry." International Journal of Supply Chain Management 8 (3): 854-864.

16. Hartinah, S., Suharso, P., Umam, R., Syazali, M., Lestari, B., Roslina, R., \& Jermsittiparsert, K. 2020. "Teacher's Performance Management: The Role of Principal's Leadership, Work Environment and Motivation in Tegal City, Indonesia." Management Science Letters 10 (1): 235-246.

17. Haseeb, M., Hussain, H., Slusarczyk, B., \& Jermsittiparsert, K. 2019. "Industry 4.0: A Solution towards Technology Challenges of Sustainable Business Performance.” Social Sciences 8 (5): 184

18. Haseeb, M., Hussain, H., Kot, S., Androniceanu, A., \& Jermsittiparsert, K. 2019. "Role of Social and Technological Challenges in Achieving a Sustainable Competitive Advantage and Sustainable Business Performance." Sustainability 11 (14): 3811

19. Haseeb, M., Kot, S., Hussain, H., \& Jermsittiparsert, K. 2019 "Impact of Economic Growth, Environmental Pollution, and Energy Consumption on Health Expenditure and R and D Expenditure of ASEAN Countries." Energies 12 (19): 3598

20. Huda, S., Tsani, I., Syazali, M., Umam, R., \& Jermsittiparsert, K. 2020. "The Management of Educational System Using Three Law Auguste Comte: A Case of Islamic Schools.” Management Science Letters 10 (3) (In press), DOI: 10.5267/j.msl.2019.9.018.

21. Usak, M., Kubiatko, M., Shabbir, M., Dudnik, O., Jermsittiparsert, K., \& Rajabion, L. 2019. "Health Care Service Delivery Based on the Internet of Things: A Systematic and Comprehensive Study.' International Journal of Communication Systems 32 (14): e4179.

22. Jermsittiparsert, K., Ambarita, D., Mihardjo, L., \& Ghani, E. 2019. "Risk-Return through Financial Ratios as Determinants of Stock Price: A Study from ASEAN Region.” Journal of Security and Sustainability Issues 9 (1): 199-210.

23. Thabhiranrak, T. \& Jermsittiparsert, K. 2019. "Towards Sustainable Functioning of Organization: Women Empowernment and Corporate Management Culture.” Journal of Security and Sustainability Issues 9 (1): 321-332 